\title{
Strategi Komunikasi Pemasaran Wuling Motors Indonesia dalam Bersaing di Industri Mobil Indonesia
}

\author{
Jeffrey Shan Budiono ${ }^{1}$, Yugih Setyanto ${ }^{2 *}$ \\ ${ }^{1}$ Fakultas Ilmu Komunikasi Universitas Tarumanagara, Jakarta \\ Email: jshan2025@gmail.com \\ ${ }^{2}$ Fakultas Ilmu Komunikasi Universitas Tarumanagara, Jakarta* \\ Email: yugihs@ fikom.untar.ac.id
}

Masuk tanggal : 15-12-2021, revisi tanggal : 06-01-2022, diterima untuk diterbitkan tanggal : 16-01-2022

\begin{abstract}
Japanese and European automobiles have ruled Indonesian industries of cars, as long from the first year they arrived in Indonesia. Meanwhile, from the land of the Red Dragon, Chinese automobiles seem to struggle and look sluggish when competing in Indonesia, from the first arrival of Chery and Geely, as the first Chinese car brand in Indonesia. From disappointing engine performance to pathetic car quality, slowly forming negative stigma about Chinese cars in Indonesia. The table turned when Wuling as the new competitor in Indonesia from China took place to compete against older brands like Toyota and Honda. This essay will discuss and examine the marketing communication strategies of Wuling Motors Indonesia as a Chinese car brand whom succeed in competing in Indonesia. The purpose of this research is to find out about Wuling marketing communication strategies used for competing in Indonesian automobile industries. From the result of this research, Wuling makes use of product review in the form of video made by credible automotive YouTuber for their YouTube channel, as the most effective way to introduce and promote their line of products to the public.
\end{abstract}

Keyword: car industry, marketing communication strategy, Wuling Motors

\begin{abstract}
Abstrak
Merek-merek mobil dari negeri Jepang dan Eropa sudah merajai industri mobil di Indonesia, sejak pertama kalinya hadir di Indonesia. Sementara itu, dari negeri tirai bambu, merek-merek mobil Tiongkok pertama di Indonesia yaitu Chery dan Geely, terlihat terus terjebak dalam pergumulan yang sama dan lesu dalam berkompetisi di industri mobil Indonesia. Dari performa mesin yang mengecewakan sampai kualitas kendaraan yang menyedihkan, perlahanlahan membentuk stigma negatif masyarakat Indonesia mengenai kualitas mobil Tiongkok. Meja pun berputar saat Wuling sebagai kompetitor baru di Indonesia dari Tiongkok hadir untuk bersaing dengan merek-merek lama seperti Toyota dan Honda. Skripsi ini berisi pembahasan dan analisis mengenai strategi komunikasi marketing Wuling Motors Indonesia dalam bersaing di industri mobil Indonesia. Tujuan dari penelitian ini adalah untuk mengetahui strategi komunikasi pemasaran yang dilakukan oleh Wuling Motors Indonesia dalam bersaing di industri mobil Indonesia. Berdasarkan hasil penelitian, penulis menemukan hasil yang efektif mengenai strategi komunikasi pemasaran yang dilakukan oleh Wuling adalah mengundang sejumlah YouTuber yang kredibel untuk melakukan review (ulasan) mengenai produk-produk Wuling secara menyeluruh untuk diunggah di kanal YouTube Youtuber tersebut.
\end{abstract}

Keyword: industri mobil, strategi komunikasi pemasaran, Wuling Motors 


\section{Pendahuluan}

Industri mobil di Indonesia didominasi oleh segelintir merek dari negeri matahari terbit dan negeri Bavaria, yang sudah bersaing di Indonesia selama bertahuntahun, bahkan beberapa merek pun memiliki citra tertentu di mata masyarakat Indonesia. Beda cerita dari Tiongkok, dimana Chery dan Geely sebagai dua merek mobil pertama Tiongkok di Indonesia, menuai kritik negatif akan kualitas dan performa mesin serta mobil yang mengecewakan, sehingga menuai stigma negatif mengenai mobil Tiongkok di mata masyarakat Indonesia.

Wuling hadir di Indonesia pada tahun 2015 sebagai generasi kedua dari mobil Tiongkok di Indonesia, dari awal dipasarkan di Indonesia, Wuling saat ini sudah memiliki empat model mobil yang dijual, dari mobil pribadi hingga mobil komersial. (Link: https://oto.detik.com/mobil/d-1732645/faktor-kualitas-alasan-indomobil-coretchery)

Kehadiran Wuling di Indonesia menjadi momentum kebangkitan mobil Tiongkok di Indonesia, melansir dari data penjualan dari Gabungan Penjualan Kendaraan Bermotor Indonesia (GAIKINDO) di tahun 2019, Wuling menempati posisi ke-6 dari 10 besar.

Strategi yang dilakukan oleh Wuling sehingga dapat bersaing dan meraih posisi yang sedemikian rupa yaitu berupa review (ulasan) video oleh YouTuber yang kredibel mengenai produk dan fitur serta fasilitas yang ditawarkan dari produk-produk Wuling, selain itu dari pihak sales dan marketing secara inisiatif menggunakan berbagai platform media sosial seperti Instagram, YouTube, dan TikTok untuk mempromosikan produk-produk mereka beserta fitur dan fasilitas yang dimiliki dalam bentuk gambar dan video.

Wuling menunjukkan bahwa mobil Tiongkok memiliki potensi dan dapat bersaing dengan merek-merek yang sudah lama ada di Indonesia. Dalam skripsi ini, penulis membahas dan meneliti mengenai strategi komunikasi pemasaran yang dilakukan oleh Wuling Motors Indonesia dalam bersaing di industri mobil Indonesia.

Berdasarkan latar belakan di atas, dalam penelitian ini, rumusan masalahnya adalah bagaimana strategi marketing communication Wuling Motors Indonesia dalam bersaing di industri motor Indonesia. Tujuan penelitian adalah mengetahui strategi marketing communication Wuling Motors Indonesia dalam bersaing di industri motor Indonesia.

\section{Metode Penelitian}

Dalam penelitian ini, penulis menggunakan metode penelitian kualitatif. Menurut Sugiyono, penelitian kualitatif berarti adalah metode penelitian yang digunakan untuk menyelidiki, menemukan, menggambarkan, dan menjelaskan kualitas atau keistimewaan dari pengaruh sosial yang tidak dapat dijelaskan, diukur maupun digambarkan melalui pendekatan kuantitatif (Sugiyono 2009:15).

Subjek pada penelitian ini adalah Wuling Motors Indonesia, mengenai strategi komunikasi pemasaran yang dilakukan oleh Wuling pada industri mobil di Indonesia. Wuling Motor Indonesia berdiri dan masuk di tahun 2015 dengan didirikannya PT. SGMW-GENERAL MOTORS-WULING (SGMW) atau Wuling Motors Indonesia, dimana Wuling merupakan pabrikan mobil Tiongkok pertama yang mendirikan pabrik di Indonesia. Sampai saat ini, Wuling sudah berhasil menyabet peringkat ke-6 dalam penjualan mobil dalam daftar 10 besar di Indonesia, mengingat Wuling adalah merek 
Jeffrey Shan Budiono, Yugih Setyanto: Strategi Komunikasi Pemasaran Wuling Motors Indonesia dalam Bersaing di Industri Mobil Indonesia

Tiongkok dan pabrikan mobil Tiongkok memiliki reputasi yang kurang berkenan di masyarakat Indonesia.

Sementara pada bagian objek penelitian, dalam penelitian ini, penulis meneliti mengenai strategi komunikasi pemasaran Wuling Motors Indonesia khususnya di kota Jakarta dan sekitarnya. Penulis akan meneliti mengenai Wuling dalam batasan strategi komunikasi pemasaran Wuling Motors Indonesia.

Informan dan key informan dalam penelitian ini diambil berdasarkan tiga narasumber yang dibagi menjadi konsumen, penjual dan pengamat. Pada sisi konsumen, penulis mewawancarai Lukas Winarno, selaku pemilik kendaraan Wuling Almaz, selain menjadi pemilik, beliau juga memiliki pengalaman dalam dunia marketing (pemasaran) selama 15 tahun dalam bisnis pembuatan dan pemasangan mika keras dan fiberglass sebelum menjadi penatua untuk suatu gereja.

Pada sisi penjual, penulis mewawancarai dengan Agus, junior sales executive dan pemasaran untuk dealer cabang Wuling Mangga Besar. Beliau merupakan lulusan Universitas Padjadjaran angkatan 2014 fakultas Ekonomi. Beliau bergabung dengan Wuling Motors Indonesia di awal tahun 2019. Lalu pada sisi pengamat, penulis mewawancarai Daddo Nugroho, pengamat otomotif dalam industri mobil di Indonesia.

Metode yang digunakan dalam penelitian Strategi Komunikasi Pemasaran Wuling Motors Indonesia dalam bersaing di Industri Mobil Indonesia adalah metode wawancara dan metode observasi. Menurut Sugiyono, wawancara digunakan sebagai teknik pengumpulan data untuk menemukan permasalahan yang harus diteliti dan juga apabila peneliti ingin mengetahui hal-hal dari responden yang lebih mendalam. (Sugiyono, 2013:18). Lain halnya dengan observasi, menurut Sugiyono, observasi adalah suatu proses yang kompleks, suatu proses yang tersusun dari pelbagai proses biologis dan psikologis. (Sugiyono, 2014: 79).

Prosedur pengolahan dan analisis data pada penelitian ini menggunakan tiga tahap pekerjaan, yaitu reduksi data, penyajian data, dan penarikan kesimpulan. Penjelasan dari ketiga tahap tersebut adalah sebagai berikut:

a. Reduksi data: Menurut Miles dan Hubberman (1992:16), Reduksi data merupakan proses pemilihan, pemusatan perhatian pada penyederhanaan, pengabstrakan, transformasi data kasar yang muncul dari catatan-catatan lapangan. Reduksi data berfungsi untuk membatasi dan menyaring data dengan subjek dan objek yang diteliti.

b. Penyajian data: merupakan sekumpulan informasi tersusun yang memberikan kemungkinan adanya penarikan kesimpulan dan pengambilan tindakan.

c. Penarikan kesimpulan: Tahap penarikan kesimpulan berguna untuk menyimpulkan hasil penelitian dari reduksi dan penyusunan data yang sudah dilakukan sebelumnya. Tahap ini akan mencari dan memahami pola, makna dan arti, penjelasan, dan sebab-akibat dari penelitian yang dilakukan oleh penulis.

Tahap selanjutnya merupakan tahap keabsahan data, untuk menguji keorisinalitasan data milik penulis dengan melihat adanya perbedaan data dengan subjek dan objek yang dilaporkan peneliti. Pada teknik keabsahan data, penulis akan menggunakan teknik triangulasi.

Teknik triangulasi menurut Sugiyono berarti menggunakan pengumpulan data yang berbeda-beda untuk mendapatkan data dari sumber data yang sama (Sugiyono, 2012: 327). 


\section{Hasil Temuan dan diskusi}

Menurut Marvin Defleur (1976) dalam teori ketergantungan, menyatakan bahwa inti dari teori ini ada pada kondisi struktural yang ada pada masyarakat. Media massa pun berperan penting dalam mempengaruhi kondisi struktural yang ada pada masyarakat, seperti persepsi dan stigma masyarakat. Media massa dalam teori ini berperan pada proses pemeliharaan, perubahan, serta konflik dalam tatanan masyarakat.

Berdasarkan penelitian yang telah dilakukan sebelumnya, penulis menyimpulkan bahwa Wuling melakukan berbagai promosi dan pengenalan terhadap produk-produknya dengan cara mengundang YouTuber-YouTuber otomotif yang kredibel secara sumber dan informasi untuk melakukan review (ulasan) dalam bentuk video terhadap produk-produk Wuling, dimana kegiatan review ini banyak memperkenalkan serta menunjukkan fitur-fitur dan fasilitas Wuling. Video-video ini nantinya akan menjadi hak milik YouTuber yang melakukan review. Mereka akan mengunggahnya di kanal YouTube miliknya.

Mengamati komentar-komentar video mengenai produk-produk Wuling, kita dapat melihat antusiasme masyarakat terhadap produk Wuling. Kita juga dapat menduga bahwa produk Wuling sebanding dengan harga dan fasilitas serta teknologi yang ditawarkannya.

Wuling tiba di saat yang tepat, di saat seluruh masyarakat sudah melek teknologi dan dapat mengakses informasi apapun dari telepon pintar mereka, sehingga mudah bagi Wuling untuk memperkenalkan merek dan produk-produk mereka, serta memperlihatkan kebolehan dari produk-produk mereka. Berikut merupakan beberapa analisis yang diperoleh dan berkaitan dengan teori sibernetik:

\section{Youtube}

Sebagai platform media sosial berbasis video terbesar di dunia, Wuling memanfaatkan YouTube sebagai media untuk memperlihatkan dan memperkenalkan produk-produk mereka lewat video review (ulasan) mengenai produk-produk mereka yang dilakukan oleh sejumlah YouTuber yang kredibel dan terpercaya. Selain video, kolom komentar pada setiap video mengenai produk-produk Wuling pun turut digunakan untuk menggali aspirasi dan keinginan masyarakat dalam dunia otomotif di Indonesia khususnya dengan roda empat.

\section{Instagram}

Platform media sosial berbasis foto yang berasal dari negeri Paman Sam pun turut digunakan oleh Wuling dalam melakukan kegiatan promosi yang sesuai dengan strategi komunikasi pemasaran mereka, berdasarkan hasil penelitian, Instagram digunakan sebagai tempat pemberitahuan mengenai berbagai acara dan promo yang dilakukan oleh pihak Wuling serta sebagai ajang kompetisi penggemar tentang modifikasi digital (digital modification) pada mobil-mobil Wuling, juga sebagai wadah testimoni positif mengenai berbagai produk-produk Wuling yang dimiliki oleh berbagai konsumennya.

\section{TikTok}

Media sosial terlaris di Indonesia asal negeri Tirai Bambu ini tengah menjadi primadona di antara masyarakat Indonesia, beragam konten mulai dari hiburan sampai informasi sehari-hari dalam bentuk video melayang di media sosial ini. Dalam media 
Jeffrey Shan Budiono, Yugih Setyanto: Strategi Komunikasi Pemasaran Wuling Motors Indonesia dalam Bersaing di Industri Mobil Indonesia

sosial ini, pihak marketing dan sales dari masing-masing dealer Wuling mengambil langkah inisiatif untuk melakukan promosi dan tur singkat terhadap produk-produk Wuling dalam bentuk video amatir singkat, untuk menunjukkan keunggulan dari fiturfitur dan teknologi yang dimiliki oleh Wuling.

Menurut Everett M. Rodgers, teori difusi inovasi adalah teori komunikasi massa dan teori komunikasi pembangunan yang diadopsi ke dalam ranah komunikasi pemasaran, yang menjelaskan bagaimana tahap-tahap masuk dan diterimanya suatu produk baru yang menyebar ke dalam pasar. Difusi menurut Rogers adalah proses suatu inovasi yang dikomunikasikan dalam jangka waktu tertentu. Terdapat lima kategori pengadopsi inovasi, yang diantara lain adalah sebagai berikut:

- Innovator - perintis sebuah ide dan inovasi.

- Early Adopters - pelopor, pemuka pendapat yang terbuka pada ide-ide baru.

- Early Majority - Penganut dini yang bergantung pada sumber-sumber informasi informal.

- Late majority - Penganut yang bersifat skeptis pada ide-ide baru dan hanya mengadopsi produk baru untuk alasan ekonomi dan sosial.

- Laggards - Kaum keras kepala yang menolak ide-ide dan inovasi baru, dengan pemikiran yang tertutup dan berpenghasilan rendah.

Pada wawancara dengan Lukas Winarno, terungkap bahwa alasa ia mengambil produk Wuling karna dirinya skeptis akan produk tersebut bahkan berencana akan mengambil produk mobil Jepang yang sudah lama beredar di Indonesia untuk menggantikan mobil beliau saat itu. Mamun disarankan oleh teman gereja untuk mengambil salah satu produk Wuling yaitu Wuling Almaz. Persepsi Lukas pun berubah dan merekomendasikan produk-produk Wuling untuk sebagai mobil yang layak pakai dan setimpal dengan harganya yang ditawarkan.

Berdasarkan dari hasil wawancara tersebut, dengan ditelitinya hasil wawancara dengan teori difusi inovasi, Lukas Winarno berperan sebagai early majority, yaitu penganut dini yang bergantung pada sumber-sumber informasi informal, maka itu dapat disimpulkan bahwa penelitian ini membuktikan kebenaran teori difusi inovasi.

\section{Simpulan}

Kesimpulan dari penelitian ini adalah bahwa strategi komunikasi pemasaran yang dilakukan oleh Wuling lewat review (ulasan), media sosial, dan testimoni pengguna yang membuat produk-produk Wuling dapat diterima oleh masyarakat dan dapat bersaing dengan rival-rivalnya yang sudah lama bersaing di Indonesia.

\section{Ucapan Terima Kasih}

Peneliti ingin mengucapkan terima kasih kepada Fakultas Ilmu Komunikasi Universitas Tarumanagara, narasumber, serta semua pihak yang turut membantu peneliti sehingga penelitian ini dapat diselesaikan.

\section{Daftar Pustaka}

Sugiyono. (2012). Metode Penelitian Kuantitatif, Kualitatif dan R\&D. Bandung: Alfabeta. 
Suryani, Ita. (2014). Pemanfaatan Media Sosial sebagai Media Pemasaran Produk dan Potensi Indonesia dalam Upaya Mendukung ASEAN Community 2015. Jurnal Komunikasi, 8 (2), 4-7. April 2014. Terarsip di: https://journal.uii.ac.id/jurnal-komunikasi/article/viewFile/6471/5830

Tempo. (2019). Januari-November 2019, Wuling laku 17731 Unit, 2099 ekspor. Diakses dari https://otomotif.tempo.co/read/1282087/januari-november-2019wuling-laku-17-731-unit-ekspor-2-099-unit/full\&view=ok. 